\title{
ECHOCARDIOGRAPHY PARAMETERS FOR EVALUATION OF RIGHT VENTRICULAR FUNCTION IN AFTER CORRECTION OF CONGENITAL HEART DISEASES
}

\author{
R.A. RAKHIMOVA, B.I. SHUKUROV, N.K. ZOKIROV \\ Republican Research Center for Emergency Medicine, \\ Multidisciplinary Medical Center Akfa Medline, Tashkent, Uzbekistan

\section{ЭХОКАРДИОГРАФИЧЕСКИЕ ПОКАЗАТЕЛИ ФУНКЦИИ ПРАВОГО ЖЕЛУДОЧКА ПОСЛЕ КОРРЕКЦИИ ВРОЖДЕННЫХ ПОРОКОВ СЕРДЦА}

\author{
Р.А. РАХИМОВА, Б.И. ШУКУРОВ, Н.К. ЗОКИРОВ \\ Республиканский научный центр экстренной медицинсой помощи, \\ Многопрофильный медицинский центр Akfa Medline, Ташкент, Узбекистан
}

\begin{abstract}
Aim. To investigate the clinical value of the right ventricular Tei index and TAPSE by examining its relationship with the clinical characteristics of postoperative congenital heart disease patients.

Material and methods. From February 2021 to September 2021, echocardiography measurements were performed at the Multidisciplinary Medical Center Akfa Medline for 20 patients with CHD. Patients were divided into 2 groups: group 1 (11 patients) - Tei index $<0.5$, and TAPSE is less than -2 according to Z-score (mean $\geq 7$ $\mathrm{mm}$ ) group 2 ( 9 patients) - Tei index $>0.6$ and TAPSE is more than -2 according to Z-score (mean $<7 \mathrm{~mm}$ ) .

Results. The time of isovolumetric contraction of the right ventricle and the time of isovolumetric relaxation were increased and Ds (duration of the $\mathrm{S}$ wave ) of the right ventricle were shortened in patients of group 2 in comparison with patients in group 1 . The time of postoperative mechanical ventilation, aortic cross-clamping time, central venous pressure, cardiac ICU stay and the volumes from the drainage significantly distinguished between the two groups, with the shortest ventilation, aortic cross clamping time, lower central venous pressure, less ICU stay and the minimum drainage volumes were occured in patients of group 1.

Conclusion. The right ventricular Tei index and TAPSE is potentially a simple, readily available, reproducible and more sensitive indicator of right ventricular dysfunction in early postoperative period.
\end{abstract}

Keywords: Congenital heart defects, Tei index, TAPSE, Doppler echocardiography, right ventricle

\begin{abstract}
Цель. Изучить клиническую значимость индекса Теі правого желудочка и TAPSE путем изучения его взаимосвязи с клиническими характеристиками пациентов с послеоперационными врожденными пороками сердца.

Материал и методы. С февраля 2021 года по сентябрь 2021 года в Многопрофильном медицинском центре Akfa Medline были выполнены эхокардиографии 20 пациентам с ВПС. Пациенты были разделены на 2 группы: 1-я группа (11 пациентов) - индекс Tеi <0,5 и TAPSE меньше - 2 по Z-score (среднее значение $\geq 7$ мм), 2-я группа (9 пациентов) - индекс Теi> 0,6 и TAPSE больше - 2 по Z-score (в среднем $<7 \mathrm{Mm})$.

Результаты. Время изоволюметрического сокращения правого желудочка и время изоволюметрического расслабления были увеличены, a Ds (длительность S-зубца) правого желудочка были укорочены у пациентов 2-й группы по сравнению с пациентами 1-й группы. Время ИВЛ, время пережатия аорты, центральное венозное давление, пребывания в отделении интенсивной терапии сердца и объемы дренажа значительно различаются между двумя группами; с самой короткой ИВЛ, временем пережатия аорты, более низким центральным венозным давлением, меньшим пребыванием в отделении интенсивной терапии и минимальным дренажным объемом отмечено у пациентов 1-й группы.

Заключение. Индекс Теі правого желудочка и TAPSE потенциально являются простым, легко доступным, воспроизводимым и более чувствительным индикатором дисфункции правого желудочка в раннем послеоперационном периоде.
\end{abstract}

Ключевые слова: врожденные пороки сердца, индекс Tеi, TAPSE, допплерэхокардиография, правый желудочек.

https://doi.org/10.54185/TBEM/vol14_iss4/a6 
Introduction. Tetralogy of Fallot (TF) is considered a group of complex and common congenital heart defects (CHD). Several studies show that the prevalence of TF ranges from 2.8 to 3.9 per 10,000 live births, with men and women equally affected. The natural progression of these patients is unfavorable, therefore, single-stage surgical treatment in infancy is preferred. The most common complication of the early postoperative period is right ventricular failure, which is formed in violation of the anatomy of the right ventricle and progressive pulmonary regurgitation [1-3]. The main anatomical components of TF are ventricular septal defect (VSD) with anterior deviation of the outlet septal defect, leading to infundibular subpulmonary stenosis and dextroposition of the aorta with possible hypoplasia of the pulmonary artery trunk and its branches, as well as right ventricular (RV) hypertrophy [4]. Complete surgical correction was first introduced in 1955 and is now used all over the world. In the long term, residual pulmonary artery stenosis that remains after this surgery and pulmonary valve regurgitation caused by a transannular patch used to increase RV drainage leads to the development of two pathophysiological conditions of the RV that are very different from each other: right ventricular hypertrophy and dilatation right ventricle [5]. A number of non-invasive diagnostic techniques such as echocardiography, MSCT, cardiac catheterization, and MRI have been used to gain access to cardiac indicators such as dimensions, volumes and characteristics of the cardiac chamber in clinical practice. With recent advances in tissue Doppler echocardiography, the Tei index has been proposed as a simple, reproducible method for measuring regional and global right ventricular function. It has been reported that as a non-invasive Doppler measurement of ventricular function, the Tei index correlates well with other invasive and non-invasive diagnostic methods and clinical features, drug therapy of patients respectively [6-7].

The aim of the study: The present study aims to investigate the clinical value of the right ventricular Tei index and TAPSE by examining its relationship with the clinical characteristics of postoperative CHD patients.

Materials and methods : From February 2021 to September 2021, echocardiographic measurements were performed at the Multidisciplinary Medical Center Akfa Medline for 20 patients with CHD ( 8 girls and 12 boys). In 10 children out of 20 patients occurred Tetralogy of Fallot, in 3 Double outlet right ventricle Tetralogy type, in 3 ventricular septal defects with pulmonary stenosis, in 1 Ebstein anomaly, in 2 patients total anomalous pulmonary venous return and in 1 atrial septal defect with pulmonary stenosis have been occurred. Doppler ultrasound was used as a diagnostic device from Siemens Accuson. 2000 with converter 2.0-5.0 MHz. On the basis of postoperative Tei values and TAPSE patients were divided into 2 groups: group 1 (11 patients) - Tei index $<0.5$, and TAPSE is less than -2 according to Z-score (mean $\geq 7 \mathrm{~mm}$ ) group 2 ( 9 patients) - Tei index $>0.6$ and TAPSE is more than -2 according to Z-score (mean $<7 \mathrm{~mm}$ ). For each circulatory situation, the duration was measured from the peak of the R-wave on the electrocardiogram to the onset of the late diastolic A wave of the next cardiac cycle. The duration of the systolic wave $S$ (Ds) was measured as the interval from the beginning to the end of the right ventricular outflow profile. The sum of the time of isovolumetric contraction and the time of isovolumetric relaxation was measured as the interval from the cessation to the beginning into the tricuspid inflow. The measurement of TAPSE involves obtaining an apical four-chamber ultrasound view, placing the M-mode line at the lateral tricuspid valve annulus (where the valve leaflet attaches to the wall of the right ventricle), obtaining an M-mode tracing and measuring the height of the annulus movement during systole.
Results : There were statistical differences in the Tei-index and TAPSE values between the 2 study groups $(P<0.05)$. The time of isovolumetric contraction of the right ventricle (71.2 $\pm 12.56 \mathrm{~m} / \mathrm{s}$ ) and the time of isovolumetric relaxation were increased $(82.45 \pm 19.78 \mathrm{~m} / \mathrm{s})$, and Ds of the right ventricle were shortened in patients of group $2(225.67 \pm 14.28 \mathrm{~m} / \mathrm{s})$ in comparison with patients in group 1 (58.34 $\pm 5.486 \mathrm{~m} / \mathrm{s}$; $62.56 \pm 11.74 \mathrm{~m} / \mathrm{s} ; 284.89 \pm 12.78 \mathrm{~m} / \mathrm{s}$ ). Thus, TAPSE was $\geq 7 \mathrm{~mm}$ in group 1 and $<7 \mathrm{~mm}$ in group 2 . The Ds of the right ventricle was somewhat declined compared to that in group 1. Clinical investigations showed that the time of postoperative mechanical ventilation, aortic cross-clamping time, central venous pressure, cardiac ICU stay and the volumes from the drainage significantly distinguished between the two groups, with the shortest ventilation, aortic cross clamping time, lower central venous pressure, less ICU stay and the minimum drainage volumes were occured in patients of group 1 (mechanical ventilation time $15.7 \pm 8.76$ hours; aortic cross-clamping time $16-28$ minutes, central venous pressure 4-6 $\mathrm{mmHg}$, drainage volumes - $205.6 \pm 85.9 \mathrm{ml}, 2-3$ day ICU stay). The time for the provision of drug treatment and stay in the ICU in patients of group 1 with the lowest Tei value, the time for both the provision of drug treatment and the stay in the ICU was slightly, but substantially increased compared in patients of group 2 - the time of mechanical ventilation $27.4 \pm$ 15.48 hours; aortic cross-clamping time 23-37 minutes, central venous pressure $7-11 \mathrm{mmHg}$, volumes from drainage - 399.8 $\pm 187.5 \mathrm{ml}$ and ICU stay $-4-5$ days $(P<0.05)$. Left ventricular ejection fraction did not significantly differ between groups and was within the normal range in all patients.

Discussions. Right ventricular systolic and diastolic dysfunction often occurs in patients after right -sided surgical correction of CHD. In patients with restrictive physiology, abnormal patterns of transtricuspid blood flow were observed, as evidenced by a lower peak E velocity and a lower E / A velocity ratio. There are various mechanisms that can lead to RV limitation, for example, inadequate intraoperative protection and chronic hypoxemia [8] . In the clinical management of patients with CHD, the assessment of the global function of the right ventricle is crucial. CT scan and cardiac catheterization have proven helpful in assessing right ventricular function. However, these methods are not suitable for young children because they require deep sedation [9]. Echocardiography, described as a simple, safe, reproducible and non-invasive method for determining the systolic and diastolic function of the heart, has received widespread acceptance by patients and doctors. Although there are many parameters that can be used to quantify ventricular function, most of them indicate left ventricular physiology. An ideal parameter for quantifying right ventricular function has not been established given the complex geometry of the right ventricle with extensive trabecularization. Pathological examination of the right ventricle revealed complex pathological features involving both systolic and diastolic dysfunction, which were correlated with each other. An easily measurable Doppler index, the Tei index, has recently been proposed, combining systolic and diastolic time intervals. The Tei index is a function of both systolic and diastolic time intervals and appears to be sensitive to disturbances in systolic and diastolic cardiac function. It has been suggested that this is the most discriminatory index with good reproducibility [10]. Mahapatra suggested that this index is a sensitive quantitative method for assessing right ventricular function with wide clinical application. Since the Tei index is essentially a time ratio [11], it does not depend on the geometry of the ventricle, heart rate, preload and can be especially useful in assessing the global function of the right ventricle in various pathophysiological conditions. However, the clinical consequences of an elevated 
right ventricular Tei in tetralogy of Fallot and other right sided CHD reconstructed patients have not been systematically evaluated. Our preliminary data suggest that the Tei index is potentially a simple, readily available, reproducible, and more sensitive indicator of right ventricular dysfunction and is clinically important for better understanding right ventricular function after surgical correction of CHD, which confirms the results of previous studies [12]. However, this index also has some limitations, sometimes it lacks sensitivity and has a slightly low negative predictive power due to a substantial number of false negative results. In addition, it has also been suggested that the Tei index may be good for measuring regional right ventricular function, but is not accurate in global functional assessment due to right ventricular outflow tract dysfunction [13]. A reduction in TAPSE after cardiac surgery is a wellknown phenomenon and has been previously reported in both congenital and acquired diseases [14]. This observation has been interpreted as an isolated worsening of right ventricular performance, without changes in left ventricle parameters or exercise capacity and thus with poor clinical significance. Several hypotheses have been proposed to explain this loss in right ventricular performance detected along the long axis, including cardiopulmonary bypass use [15], geometrical changes of the right ventricular chamber (in association with interventricular septal paradoxical motion ), intraoperative ischaemia, right atrial injury due to cannulation procedure, poor myocardial protection , and extramyocardial causes (pericardial disruption, changes in fossa ovale, and postoperative adherence of the right ventricle to the thoracic wall [16]).

Conclusions. The results of this trial indicate that the right ventricular Tei index and TAPSE is potentially a simple, readily available, reproducible and more sensitive indicator of right ventricular dysfunction. The elevated right ventricular Tei index and decreased TAPSE found in pediatric patients after correction of CHD was statistically correlated with prolonged postoperative ventilation, aortic cross-clamping time, higher central venous pressure, more ICU stay and more drainage volumes.

\section{References :}

1. Narcissova G.P., Prokhorova D.S., Matveeva N.V. Evaluation of pulmonary regurgitation by Doppler echocardiography in a clinical study of patients after radical correction of Fallot's tetrad. Circulatory Pathology and Cardiac Surgery 2012; 16 (2): 15-19.

2. Sukhanov S.G., Orekhova E.N., Sinel'nikov Yu.S. Mechanical function of the right ventricle in children of the first year of life with tetralogy of Fallot. Circulatory pathology and cardiac surgery 2015; 19 (3): 19-25.

3. Hamilton D.I., Di Eusanio., Piccoli G.P. Eight years experience with intracardiac repair of tetralogy of Fallot. Early and late results in 175 consecutive patients. $\mathrm{Br}$ Heart J 1981; 46 (2): 144-151.

4. Ossa Galvis MM, Mendez MD. Cyanotic heart disease. Treasure Island,FL: StatPearls Publishing; 2019.

5. Kjaergaard J, Iversen KK, Akkan D, Moller JE, Kober LV, Torp-PedersenC, Hassager C. Predictors of right ventricular function as measured bytricuspid annular plane systolic excursion in heart failure. CardiovascUltrasound 2009; 7:51.

6. Grignola JC, Ginés F, Guzzo D. Comparison of the Tei index with invasive measurements of right ventricular function. Int J Cardiol. 2006;113:25-33.

7. Su HM, Lin TH, Voon WC, Lee KT, Chu CS, Yen HW, Lai WT, Sheu SH. Correlation of Tei index obtained from tissue Doppler echocardiography with invasive measurements of left ventricular performance. Echocardiography. 2007;24:252-257.

8. Sachdev MS, Bhagyavathy A, Varghese R, Coelho R, Kumar RS. Right ventricular diastolic function after repair of tetralogy of Fallot. Pediatr Cardiol 2006; 27:250-255

9. Ding J, Ma G, Huang Y, Zhang X, Zhu J, Yang R, Lu F. Usefulness of myocardial performance index for assessing right ventricular function after percutaneous closure of atrial septal defect. Journal of Geriatric Cardiology. 2007;4:220-224.

10. Ling LH, Tei C, McCully RB, Bailey KR, Seward JB, Pellikka PA. Analysis of systolic and diastolic time intervals during dobutamine-atropine stress echocardiography: diagnostic potential of the Doppler myocardial performance index. J Am Soc Echocardiogr. 2001;14:978-986.

11. Ishii M, Tsutsumi T, Himeno W, Eto G, Furui J, Hashino K, Sugahara Y, Muta H, Akagi T, Ando A. Sequential evaluation of left ventricular myocardial performance in children after anthracycline therapy. $\mathrm{Am} \mathrm{J}$ Cardiol. 2000;86:1279-1281.

12. Leonard GT Jr, Fricker FJ, Pruett D, Harker K, Williams B, Schowengerdt KO Jr. Increased myocardial performance index correlates with biopsy-proven rejection in pediatric heart transplant recipients. J Heart Lung Transplant. 2006;25:61-66.

13. Kutty S, Zhou J, Gauvreau K, Trincado C, Powell AJ, Geva T. Regional dysfunction of the right ventricular outflow tract reduces the accuracy of Doppler tissue imaging assessment of global right ventricular systolic function in patients with repaired tetralogy of Fallot. J Am Soc Echocardiogr. 2011;24:637-643.

14. Alam M., Hedman A., Nordlander R., Samad B. Right ventricular function before and after an uncomplicated coronary artery bypass graft as assessed by pulsed wave Doppler tissue imaging of the tricuspid annulus. American Heart Journal. 2003;146(3):520-526. doi: 10.1016/S0002-8703(03)00313-2.

15. Forsberg L. M., Tamás É., Vánky F., Nielsen N. E., Engvall J., Nylander E. Left and right ventricular function in aortic stenosis patients 8 weeks posttranscatheter aortic valve implantation or surgical aortic valve replacement. European Journal of Echocardiography. 2011;12(8):603-611. doi: 10.1093/ ejechocard/jer085.

16. Unsworth B., Casula R. P., Yadav H., et al. Contrasting effect of different cardiothoracic operations on echocardiographic right ventricular long axis velocities, and implications for interpretation of post-operative values. International Journal of Cardiology. 2013;165(1):151-160. doi: 10.1016/j.ijcard.2011.08.031. 


\title{
ЧАП ҚОРИНЧАСИ ФУНКЦИЯСИНИНГ ЮРАК ТУҒМА НУҚСОНЛАРИ БАРТАРАФ ҚИЛИНГАНДАН СЎНГИ ЭХОКАРДИОГРАФИК КЎРСАТКИЧЛАРИ
}

\author{
Р.А. РАХИМОВА, Б.И. ШУКУРОВ, Н.К. ЗОКИРОВ
}

\begin{abstract}
Мақсад. Ўнг қоринчанинг эхокардиографик Теі индекс ва TAPSE кўрсаткичлари бўйича юрак туғма нуқсонларида операциядан кейинги клиник кўрсаткичларни тахлил қилиш.

Материал ва усуллар. 2021 йил февраль ва сентябрь ойларида кўп тармоқли Акфа Медлайн тиббиёт марказида юрак туғма нуқсонли 20 та беморда эхокардиографик текширувлар ўтказилди. Беморлар 2 гурухга ажратилди: 1-гурух (11 бемор) Теі индекси <0,5 ва TAPSE Z-score бўйича -2 дан паст (ўртача кўрсаткич $\geq 7$ мм) 2-гурух (9 бемор) - Теі индекси <0,5 ва TAPSE Z-score бўйича -2 дан баланд (ўртача кўрсаткич <7 мм) .

Натижалар. 2-гурух беморларда 1-гурухга нисбатан ўнг қоринча изоволюметрик кисқариш ва кенгайиш вақти узайиши, S тишча давомийлиги эса қисқариши кузатилди. Ўпка сунъий вентиляцияси вақти, аорта сиқилиш вақти, марказий вена босими, беморнинг интенсив терапия бўлимида даволаниш давомийлиги ва дренаж найча суюқлик хажми гурухлар ўртасида бир-биридан сезиларли фарқланиши кузатилди. 1-гурух беморларда қисқа ўпка сунъий вентиляцияси, аорта сиқилиш вақти, паст марказий вена босими, кам вақт интенсив терапия бўлимида даволаниш давомийлиги ва кам дренаж найча суюқлик хажми кузатилди.

Хулоса. Ўнг қоринчанинг эхокардиографик Теі индекс ва TAPSE кўрсаткичлари эрта операциядан кейинги даврдаги ўнг қоринча функциясини бахоловчи оддий, осон бажарилувчи ва самарали текширув усули хисобланади.
\end{abstract}

Калит сўзлар: туғма юрак нуқсонлари, Теі индекси, ТАPSE, допплерэхокардиография, ўнг қоринча.

\section{Сведения об авторах :}

Рахимова Раъно Абдухакимовнакандидат медицинских наук, заведующая отделением ультразвуковой диагностики Республиканского научного центра экстренной медицинской помощи.

Шукуров Бобир Ибрагимович -

кандидат медицинских наук, старший научный сотрудник отдела экстренной хирургии Республиканского научного центра экстренной медицинской помощи.

\section{Зокиров Нодиржон Комилжон угли -}

врач-кардиолог и врач функциональной диагностики многопрофильного медицинского центра Akfa Medline.

E-mail: znodirshoh@yahoo.com.

Поступила в редакцию: 05.07.2021

\section{Information about authors:}

Rakhimova Ra'no Abduhakimovna-

$\mathrm{PhD}$, Head of the Department of Ultrasound Diagnostics at Republican Research Center for Emergency medicine.

Shukurov Bobur Ibragimovich-

PhD, Senior Researcher of the Emergency Surgery

Department of the Republican Scientific Center

of Emergency Medicine.

Zokirov Nodirjon Komiljon o'gli -

MD, Cardiologist and functional diagnostics at Republican

Research Center for Emergency medicine.

E-mail: znodirshoh@yahoo.com

Received: 05.07.2021 